www.nature.com/ejhg

\title{
REVIEW
}

\section{XLMR genes: update 2000}

\author{
Pietro Chiurazzi ${ }^{1}$, Ben CJ Hamel ${ }^{2}$ and Giovanni Neri ${ }^{\star, 3}$
}

${ }^{1}$ Institute of Medical, Preventive and Social Pediatrics, University of Messina, Messina, Italy; ${ }^{2}$ Department of Human Genetics, University Medical Centre Nijmegen, Nijmegen, The Netherlands; ${ }^{3}$ Institute of Medical Genetics, Catholic University, Rome, Italy

This is the sixth edition of the catalogue of XLMR genes, ie X-linked genes whose malfunctioning causes mental retardation. The cloning era is not yet concluded, actually much remains to be done to account for the 202 XLMR conditions listed in this update. Many of these may eventually prove to be due to mutations in the same gene but the present number of 33 cloned genes falls surely short of the actual total count. It is now clear that even small families or individual patients with cytogenetic rearrangements can be instrumental in pinning down the remaining genes. DNA chip technology will hopefully allow (re)screening large numbers of patients for mutations in candidate genes or testing the expression levels of many candidate genes in informative families. Slowly, our knowledge of the structure and functioning of the proteins encoded by these genes is beginning to cast some light on the biological pathways required for the normal development of intelligence. Correlations between the molecular defects and the phenotypic manifestations are also being established. In order to facilitate the exchange of existing information and to allow its timely update, we prepared the first edition of the XLMR database (available at http://homepages.go.com/ xlmr/home.htm) and invite all colleagues, expert in the field, to contribute with their experience. European Journal of Human Genetics (2001) 9, $71-81$.

Keywords: mental retardation; X chromosome; XLMR; MRXS; MRX; on-line database

\section{Introduction}

Mental retardation (MR) can be defined as a failure to develop cognitive abilities and achieve a level of intelligence that would be appropriate for the age group. In most cases MR causes a deficit in the 'adaptive behaviour'. A percentage of the general population, variably estimated between 0.5 and $2 \%$, is reported to be functioning two standard deviations below the average (ie to have an IQ of less than 70). Genetic determinants underlie many of these conditions ${ }^{1}$ and an excess of affected males has often been reported, ${ }^{2,3}$ especially in the mild-to-moderate MR range (IQ between 70 and 35). This phenomenon was eventually interpreted as being due to $\mathrm{X}$-linked mutations, whose effects become more apparent in the hemizygous males who cannot compensate for deleterious mutations present on their $\mathrm{X}$ chromosome. ${ }^{2,4}$ Herbst

*Correspondence: G Neri, MD, Istituto di Genetica Medica, Universita' Cattolica, Largo F Vito 1, 00168 Rome, Italy. Tel: +39 06305 4449; Fax: +39 06305 0031; E-mail: gneri@rm.unicatt.it Received 14 August 2000; revised 25 October 2000; accepted 26 October 2000 and Miller ${ }^{5}$ estimated the frequency of X-linked mental retardation (XLMR) at 1.8/1000 males in British Columbia. Recently the prevalence of the fragile $\mathrm{X}$ syndrome, probably the commonest of XLMR conditions, has been re-estimated at $1 / 4000$ males at most $^{6}$ and may represent up to $15-20 \%$ of the total XLMR. Neri et $a l^{7}$ prepared the first XLMR update in 1990 and tried to include all X-linked forms of mental retardation in their listing, which steadily grew to the total number of 179 entries in the previous update. ${ }^{8}$ This XLMR update 2000 now lists 202 conditions subdivided in different nosological classes that will be illustrated in the next section.

\section{Information sources and classification of XLMR conditions}

The information sources employed to compile this listing have been many and diverse. First of all, we have regularly scanned the published literature, ie articles in scientific journals and abstracts presented at the American Society of Human Genetics, the European Society of Human Genetics and the biannual International Workshop on Fragile $\mathrm{X}$ and 
Table 1 Malformation syndromes

\begin{tabular}{|c|c|c|c|c|}
\hline MIM No. & Name & Locus & Gene & Description \\
\hline *305400 & Aarskog-Scott & $\mathrm{Xp11.21}$ & FGDY & $\begin{array}{l}\text { Hypertelorism, short stature, downslanting palpebral fissures, } \\
\text { anteverted nostrils, shawl scrotum, joint hyperlaxity }\end{array}$ \\
\hline 304200 & Akesson & & & Cutis verticis gyrata, thyroid aplasia \\
\hline \#301040 & ATR-X & Xq13 & $\begin{array}{l}X H 2 / X N P \\
* 300032\end{array}$ & $\begin{array}{l}\text { Microcephaly, 'coarse' face, genital and skeletal anomalies, } \\
\text { alpha-thalassemia. It includes Juberg-Marsidi (\#309590), } \\
\text { Carpenter-Waziri, }{ }^{15} \text { Holmes-Gang, }{ }^{16} \text { a family with spastic } \\
\text { diplegia }{ }^{17} \text { and possibly }{ }^{18} \text { Smith-Fineman-Myers (309580) }\end{array}$ \\
\hline *301900 & $\begin{array}{l}\text { Borjeson-Forssman- } \\
\quad \text { Lehmann }\end{array}$ & Xq26-q27 & & $\begin{array}{l}\text { Obesity, hypogonadism, round face, narrow palpebral fissures, } \\
\text { epilepsy }\end{array}$ \\
\hline 301950 & Branchial arch & & & $\begin{array}{l}\text { Short stature, downslanting eyes, lowset ears, webbed neck, } \\
\text { highly arched palate }\end{array}$ \\
\hline 308830 & Cantu' & & & Macrocephaly, dwarfism, keratosis follicularis \\
\hline *309620 & Christian & Xq27-q28 & & Skeletal dysplasia, VI nerve palsy \\
\hline *300243 & Christianson & $\mathrm{Xq} 23-\mathrm{q} 27.3$ & & $\begin{array}{l}\text { Profound MR, mutism despite normal hearing, craniofacial } \\
\text { dysmorphism, grand-mal epilepsy, ophthalmoplegia, cerebellar } \\
\text { atrophy }\end{array}$ \\
\hline 309490 & Chudley-Lowry & & & Short stature, obesity, small genitalia \\
\hline \#303600 & Coffin-Lowry & Xp22.2-p22.1 & $\begin{array}{l}\text { RSK2 } \\
* 300075\end{array}$ & $\begin{array}{l}\text { 'Coarse' face, drumstick phalanges, skeletal anomalies. It includes } \\
\text { MRX1912 }\end{array}$ \\
\hline \#305000 & $\begin{array}{r}\text { Dyskeratosis } \\
\text { congenita }\end{array}$ & $\mathrm{Xq} 28$ & $\begin{array}{l}D K C 1 \\
* 300126\end{array}$ & Skin pigmentation, nail dystrophy, leukoplakia of oral mucosa \\
\hline *305450 & FG & $\mathrm{Xq12-q21.3}$ & & $\begin{array}{l}\text { Macrocephaly, agenesis of corpus callosum, gastrointestinal } \\
\text { anomalies, deafness }\end{array}$ \\
\hline *309550 & Fragile $X$ & $\mathrm{Xq} 27.3$ & FMR1 & Macrocephaly, long face and ears, macro-orchidism \\
\hline 301590 & Graham & & & Anophthalmos, ankyloblepharon, orbital underdevelopment \\
\hline *302000 & $\begin{array}{l}\text { Hereditary } \\
\text { bullous } \\
\text { dysfunction }\end{array}$ & $\mathrm{Xq} 27.3-\mathrm{q} 28$ & & $\begin{array}{l}\text { Short stature, microcephaly, alopecia, bullous dystrophy, } \\
\text { hypogenitalism }\end{array}$ \\
\hline 300064 & Hyde-Forster & & & Craniofacial anomalies with plagiocephaly, flattened occiput \\
\hline 307010 & $\begin{array}{l}\text { Hydrocephalus with } \\
\text { cerebellar agenesis }\end{array}$ & & & $\begin{array}{l}\text { Hydrocephalus, cerebellar agenesis, absence of Magendie and } \\
\text { Luschka's foramina }\end{array}$ \\
\hline *309800 & Lenz & Xq27-q28 & & $\begin{array}{l}\text { Microphthalmia, thumb and skeletal anomalies, urogenital and } \\
\text { cardiovascular anomalies. It includes Siber } \text { et } \text { al. }^{21}\end{array}$ \\
\hline *309520 & Lujan-Fryns & & & $\begin{array}{l}\text { Marfanoid habitus, triangular face, narrow palate, hypernasal } \\
\text { voice }\end{array}$ \\
\hline *309605 & Miles/MRXS4 & $X p 11.2-q 23$ & & $\begin{array}{l}\text { Microcephalus, asymmetric face, hypogonadism, joint } \\
\text { hypermobility, } 10 \text { digital arches }\end{array}$ \\
\hline *302350 & Nance-Horan & Xp22.31-p22.13 & & $\begin{array}{l}\text { Cataract, microcornea, cone-shaped incisors, supernumerary } \\
\text { teeth }\end{array}$ \\
\hline *300000 & Opitz G/BBB & $\mathrm{Xp} 22$ & MID1 & Hypertelorism, midline abnormalities, heart defects, hypospadias \\
\hline *311300 & Oto-palato-digital & Xq27-q28 & & Short stature, hearing loss, cleft palate, characteristic face \\
\hline *309510 & Partington/MRXS1 & Xp22.2-p22.1 & & Dysarthria, dystonic hand movements, ataxia, seizures \\
\hline *304340 & Pettigrew/MRXS5 & $X q 26-q 27.1$ & & $\begin{array}{l}\text { Long 'coarse' face, hydrocephalus, hypotonia, spasticity, ataxia, } \\
\text { seizures, iron accumulation in basal ganglia, Dandy-Walker } \\
\text { anomaly }\end{array}$ \\
\hline 300055 & PPM-X & $\mathrm{Xq} 28$ & & Psychosis, pyramidal signs, macro-orchidism \\
\hline *309610 & Prieto/MRXS2 & Xp21.1-p11.3 & & $\begin{array}{l}\text { Peculiar face, dental anomalies, sacral dimple, joint dysplasia, } \\
\text { epilepsy }\end{array}$ \\
\hline 300004 & Proud & & & $\begin{array}{l}\text { Microcephaly, agenesis of corpus callosum, arthrogryposis, renal } \\
\text { dysplasia, hypospadias }\end{array}$ \\
\hline *309500 & Renpenning/MRXS8 & Xp11.4-p11.2 & & Microcephaly, short stature \\
\hline 308200 & Rud & $\mathrm{Xp} 22$ & & Ichthyosis, epilepsy, nystagmus, hypogonadism \\
\hline 314320 & Say-Meyer & & & Trigonocephaly, short stature \\
\hline 312840 & Schimke & & & $\begin{array}{l}\text { Early onset choreoathetosis with later spasticity, microcephaly, } \\
\text { growth failure, external ophthalmoplegia, variable deafness }\end{array}$ \\
\hline \#312870 & $\begin{array}{l}\text { Simpson-Golabi- } \\
\text { Behmel }\end{array}$ & $\mathrm{Xq} 26$ & $\begin{array}{l}\text { GPC3 } \\
* 300037\end{array}$ & $\begin{array}{l}\text { Macrosomia, 'coarse' face, polydactyly, extra nipples, heart } \\
\text { defects }\end{array}$ \\
\hline 309580 & $\begin{array}{l}\text { Smith-Fineman- } \\
\text { Myers }\end{array}$ & & & Peculiar face, microcephaly, short stature, seizures \\
\hline *309583 & Snyder-Robinson & $\mathrm{Xp} 22.2-\mathrm{p} 21.2$ & & $\begin{array}{l}\text { Macrocephaly, long thin face, high narrow/cleft palate, asthenic } \\
\text { body build, scoliosis }\end{array}$ \\
\hline *309470 & Sutherland/MRXS3 & Xp11.3-q12 & & Microcephaly, short stature, small testes, spastic diplegia \\
\hline 309480 & Tranebjaerg I & & & Epilepsy, psoriasis \\
\hline *314390 & $\begin{array}{l}\text { VACTERL with } \\
\text { hydrocephalus }\end{array}$ & & & $\begin{array}{l}\text { Vertebral, anal, tracheo-esophageal, renal and radial defects, } \\
\text { hydrocephalus }\end{array}$ \\
\hline
\end{tabular}


Table 1 (Continued)

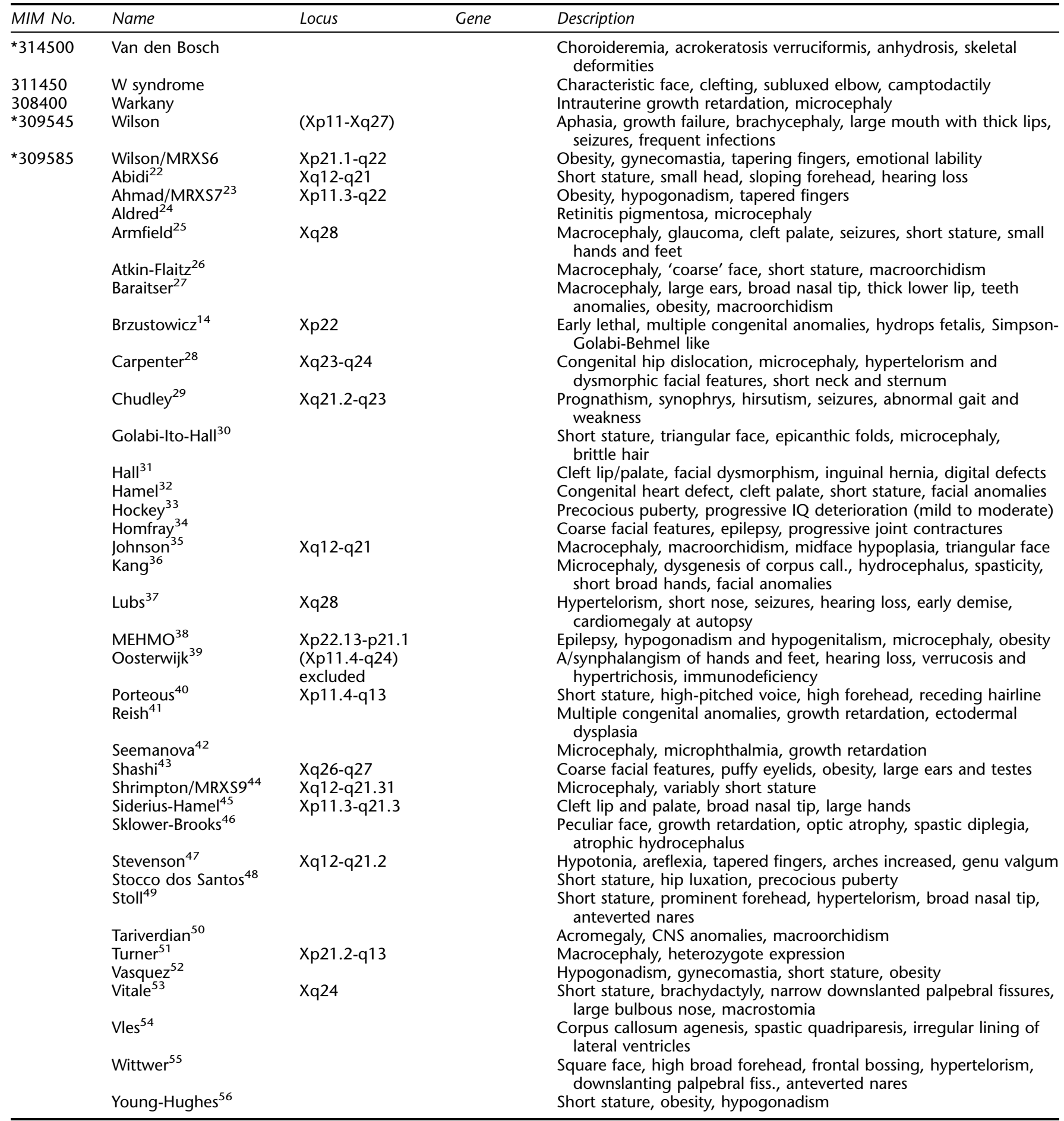

XLMR. The On-line Mendelian Inheritance in Man (OMIM) catalogue was often checked and provided valuable information and references (available at http://www.ncbi.nlm.nih.gov/omim/). For approximately 560 entries listed in the
OMIM catalogue, MR is mentioned in the clinical synopsis and 90 (16\%) of these are X-linked (as per June 30, 2000). Lastly, some inclusions and exclusions were suggested to us by many colleagues, whose advice was extremely helpful. It is 
Table 2 Neuromuscular disorders

\begin{tabular}{|c|c|c|c|c|}
\hline MIM No. & Name & Locus & Gene & Description \\
\hline *309600 & $\begin{array}{l}\text { Allan-Herndon- } \\
\text { Dudley }\end{array}$ & Xp11.4-q22 & & Severe hypotonia, joint contractures, muscular atrophy \\
\hline *302500 & Apak & & & Spinocerebellar ataxia, nystagmus, dysarthria \\
\hline *301835 & Arts & Xq21.33-q24 & & $\begin{array}{l}\text { Early death, hypotonia, ataxia, deafness, loss of vision, recurrent } \\
\text { infections }\end{array}$ \\
\hline 301840 & Ataxia-dementia & & & Ataxia, pyramidal tract signs, adult-onset dementia \\
\hline 312890 & Baar-Gabriel & & & Athetotic spastic paraplegia \\
\hline 309660 & Bergia & & & $\begin{array}{l}\text { Cardiomyopathy (lethal), scapuloperoneal muscular dystrophy, } \\
\text { myopia }\end{array}$ \\
\hline *302801 & CMTX2 & $\mathrm{Xp22.3-1}$ & & Motor-sensory neuropathy, formerly listed as Ionasescu (Family 1) \\
\hline *310490 & $\begin{array}{l}\text { Cowchock- } \\
\text { Fishbeck }\end{array}$ & Xq24-q26.1 & & $\begin{array}{l}\text { Motor-sensory neuropathy and deafness. It is possibly allelic to } \\
\left.\text { CMTX3 [ }{ }^{*} 302802\right]\end{array}$ \\
\hline *310200 & $\begin{array}{l}\text { Duchenne } \\
\text { muscular } \\
\text { dystrophy }\end{array}$ & Xp21.3-1 & $D M D$ & Pseudohypertrofic muscular dystrophy \\
\hline 309560 & Fitzsimmons & & & Spastic paraplegia, pes cavus, palmoplantar hyperkeratosis \\
\hline \#312920 & Goldblatt & Xq13-q21.1 & & Complicated spastic paraplegia with nystagmus and optic atrophy \\
\hline *309555 & Gustavson & $x q 25-q 26$ & & $\begin{array}{l}\text { Optic atrophy, hearing loss, epilepsy, spasticity, restricted joint } \\
\text { mobility, early death }\end{array}$ \\
\hline \#307000 & HSAS & Xq28 & $\begin{array}{l}\text { L1CAM } \\
* 308840\end{array}$ & $\begin{array}{l}\text { Hydrocephalus with stenosis of the aqueduct of Silvius. It includes } \\
\text { spastic paraplegia I [\#312900] and MASA [\#303350] }\end{array}$ \\
\hline *304100 & Menkes-Kaplan & & & Partial agenesis of corpus callosum, seizures \\
\hline *304700 & Mohr-Tranebjaerg & $\mathrm{Xq} 22$ & $D D P$ & $\begin{array}{l}\text { Hearing loss, visual impairment, ataxia, spastic paraplegia. It includes } \\
\text { Jensen [\#311150] }\end{array}$ \\
\hline *310600 & Norrie & Xp11.3 & NDP & Blindness, hearing loss \\
\hline *311050 & OPA-2 & Xp11.4-p11.21 & & Optic atrophy, abnormal reflexes, dysarthria, tremor \\
\hline 311400 & Paine \& Seemanova & & & Spastic diplegia, myoclonic seizures, cerebellar hypoplasia \\
\hline *312080 & $\begin{array}{l}\text { Pelizaeus- } \\
\text { Merzbacher }\end{array}$ & Xq21.33-q22 & $P L P$ & $\begin{array}{l}\text { Spasticity, cerebellar ataxia, parkinsonism. It includes spastic } \\
\text { paraplegia II [\#312920] }\end{array}$ \\
\hline 308850 & Plott & & & Laryngeal abductor paralysis \\
\hline *300220 & Reyniers/MRXS10 & Xp22.1-q21.3 & & Choreoathetosis, dysarthria, psychosis \\
\hline 301790 & Schmidley & & & Hypotonia, ataxia, sensorineural deafness, optic atrophy, early demise \\
\hline \#300067 & SCLH/XLIS & $X q 22.3-q 23$ & $\begin{array}{l}D C X \\
* 300121\end{array}$ & $\begin{array}{l}\text { Subcortical laminar heterotopia in females, lissencephaly and } \\
\text { epilepsy in males }\end{array}$ \\
\hline *311510 & Waisman-Laxova & Xq27.2-qter & & Parkinsonism, seizures, apparent basal ganglia degeneration \\
\hline *308350 & West & Xp21.3-p22.1 & & Infantile spasms, hypsarrythmia, early death \\
\hline \multirow[t]{12}{*}{ *314580 } & Wieacker-Wolff & Xp11.3-q13 & & $\begin{array}{l}\text { Contractures, distal muscular atrophy, dyspraxia of ocular and facial } \\
\text { muscles }\end{array}$ \\
\hline & Arena $^{57}$ & & & Spastic paraplegia, ataxia, titubation, iron deposits in basal ganglia \\
\hline & $\begin{array}{l}\text { Berry-Kravis } \\
(\mathrm{XLAG})^{58}\end{array}$ & & & $\begin{array}{l}\text { Lissencephaly with frontal pachygiria and posterior agyria, agenesis of } \\
\text { corpus callosum, neonatal epilepsy and hypotonia, hypothermia, } \\
\text { ambiguous genitalia }\end{array}$ \\
\hline & Bertini $^{59}$ & Xp22.3 & & Ataxia, hypotonia, recurrent infections \\
\hline & Cabezas $^{60}$ & $\mathrm{Xq} 22.3-\mathrm{q} 25$ & & Short stature, small testes, muscle wasting, tremor \\
\hline & Claes $^{61}$ & & & $\begin{array}{l}\text { Slowly progressive spastic paraplegia, maxillary hypoplasia, facial } \\
\text { hypotonia }\end{array}$ \\
\hline & Fried $^{62}$ & Xp22 & & Hydrocephaly, spastic diplegia, calcification of basal ganglia \\
\hline & Garcia $^{63}$ & Xp11-q13 & & Learning difficulty, epilepsy, intermittent aggressive behaviour \\
\hline & Hamel BCD 64 & Xp11.3-q21.3 & & Blindness, convulsions, hypomyelination, spasticity, early death \\
\hline & SPG $7^{65}$ & $\mathrm{Xq11.2-q23}$ & & $\begin{array}{l}\text { Quadriplegia, motor aphasia, reduced vision, dysfunction of bowel } \\
\text { and bladder }\end{array}$ \\
\hline & Tranebjaerg ${ }^{11^{66}}$ & & & Dyspraxia, ataxia, seizures, pes equinovarus, macroorchidism \\
\hline & $\mathrm{XMRE}^{67}$ & Xp21.1-p11.4 & & $\begin{array}{l}\text { Generalized tonic-clonic and atonic seizures, moderate MR, normal } \\
\text { electromyography and nerve conduction }\end{array}$ \\
\hline
\end{tabular}

inevitable that some items may have been missed or erroneously included in this listing. Any suggestions or corrections will be gratefully accepted and it is now possible to do so in real time by contributing to the on-line XLMR database. We excluded small pedigrees with uncertain Xlinkage (eg a mother with two affected sons), but such 'uncertain' families may still be extremely valuable for genetic studies and could be included in a dedicated section of the on-line XLMR database. Two affected half-brothers or an affected nephew and uncle have been considered sufficient proof of $X$ linkage.

In the nosology of XLMR, a major distinction has been made between 'nonspecific' and 'specific' or 'syndromal' conditions. According to the HUGO Nomenclature Commit- 
Table 3 Metabolic conditions

\begin{tabular}{|c|c|c|c|c|}
\hline MIM No. & Name & Locus & Gene & Description \\
\hline *300100 & Adrenoleukodystrophy & $\mathrm{Xq} 28$ & $A L D$ & Spastic quadriparesis, impaired vision, ataxia, dementia \\
\hline *300123 & MRGH & $X q 24-q 27.3$ & & $\begin{array}{l}\text { Isolated GH deficiency, short stature, small sella turcica, overlap with } \\
* 312000 ?\end{array}$ \\
\hline *307030 & Hyperglycerolemia & $\mathrm{Xp} 21.3$ & GK1 & Glyceroluria, poor growth, esotropia, osteoporosis \\
\hline *309900 & Hunter disease & $\mathrm{Xq} 28$ & IDS & $\begin{array}{l}\text { 'Coarse' face, dysostosis multiplex, dwarfism, hepato- } \\
\text { splenomegaly, heart involvement }\end{array}$ \\
\hline *308000 & Lesch-Nyhan & $\mathrm{Xq} 26$ & HPRT & Cerebral palsy, choreoathetosis, self-destructive biting \\
\hline *309000 & Lowe & $X q 25-q 26.1$ & OCRL1 & Hydrophthalmia, cataract, vitamin D-resistant rickets \\
\hline *309850 & MAO-A deficiency & Xp11.3 & $M A O A$ & Aggressive behaviour, disturbance in monoamine metabolism \\
\hline \#309400 & Menkes & Xq13 & $\begin{array}{l}\text { ATP7A } \\
* 300011\end{array}$ & $\begin{array}{l}\text { Growth retardation, peculiar hair, focal cerebral \& cerebellar } \\
\text { degeneration. It includes occipital horn syndrome or cutis } \\
\text { laxa [\#304150] }\end{array}$ \\
\hline *311250 & OTC deficiency & Xp21.1 & OTC & Hyperammonemia \\
\hline *312000 & Panhypopituitarism & $X q 25-q 26$ & & $\begin{array}{l}\text { Combined deficiency of pituitary hormones, overlap with } \\
* 300123 ?\end{array}$ \\
\hline *311800 & PGK1 deficiency & $\mathrm{Xq} 21.1$ & PGK1 & Myoglobinuria, epilepsy, hemolytic anemia \\
\hline *312170 & $\begin{array}{l}\text { Pyruvate } \mathrm{DH} \\
\text { complex E1a } \\
\text { subunit deficiency }\end{array}$ & Xp22.1 & PDHA1 & Lactic acidosis, ataxia \\
\hline
\end{tabular}

Table 4 Dominant conditions

\begin{tabular}{|c|c|c|c|c|}
\hline MIM No. & Name & Locus & Gene & Description \\
\hline *304050 & Aicardi & $\mathrm{Xp} 22$ & & $\begin{array}{l}\text { Agenesis of corpus callosum, chorioretinopathy, microphthalmia, } \\
\text { seizures }\end{array}$ \\
\hline \#300049 & BPNH & $\mathrm{Xq} 28$ & $\begin{array}{l}\text { FLN1 } \\
* 300017\end{array}$ & $\begin{array}{l}\text { Epilepsy, periventricular nodular heterotopia, mild hypoplasia of } \\
\text { corpus callosum and/or cerebellum in females; syndactyly and } \\
\text { severe MR in rare affected males }\end{array}$ \\
\hline *300088 & EFMR & $\mathrm{Xq} 21.3-\mathrm{q} 22.2$ & & MR and epilepsy in females only, males spared \\
\hline *305600 & Goltz & & & $\begin{array}{l}\text { Focal dermal hypoplasia, short missing digits, polysyndactyly, } \\
\text { microphthalmia }\end{array}$ \\
\hline \#308310 & $\begin{array}{l}\text { Incontinentia } \\
\text { pigmenti } \\
\text { Type II }\end{array}$ & $\mathrm{Xq} 28$ & $\begin{array}{l}\text { NEMO } \\
\star 300248\end{array}$ & $\begin{array}{l}\text { Incontinentia pigmenti, incomplete dentition, retinal } \\
\text { abnormalities }\end{array}$ \\
\hline *309801 & MIDAS & $\mathrm{Xp} 22$ & & Microphthalmia, dermal aplasia, sclerocornea \\
\hline *311200 & OFD1 & Xp22.2-3 & & Midline clefting of face, tongue nodules, syndactyly \\
\hline \#312750 & Rett & $\mathrm{Xq} 28$ & $\begin{array}{l}\text { MeCP2 } \\
* 300005\end{array}$ & Ataxia, autism, dementia \\
\hline
\end{tabular}

tee (http://www.gene.ucl.ac.uk/nomenclature/), the former are indicated by the acronym MRX and the latter by the acronym MRXS, where 'S' stands for 'syndromal'. The terms 'syndromal' and 'specific' are currently used interchangeably to indicate conditions that are clinically recognizable because of a specific pattern of physical, neurological, or metabolic abnormalities. ${ }^{4}$ A dedicated survey of MRXS conditions, compiled by some of the authors of this update 2000, was recently published. ${ }^{9}$ Sometimes MRX numbers were assigned to pedigrees that were eventually described as 'syndromal' and this has created some confusion. The MRX designation is actually intended for families whose only consistent clinical manifestation is X-linked MR. MRXS conditions have been somewhat arbitrarily subdivided into four classes: malformation syndromes (Table 1), neuromuscular disorders (Table 2), metabolic (Table 3) and dominant
(Table 4) conditions. By 'malformation syndrome' we mean a condition characterised by MR and multiple congenital anomalies. A 'neuromuscular disorder' is one with a major involvement of the nervous system and/or muscles. 'Metabolic' conditions are considered separately because their pathophysiology is known and due to the abnormal functioning of specific enzymes. 'Dominant' conditions have been set apart because of their peculiar inheritance, with near absence of affected males (males die before birth, with the notable exception of one form with epilepsy and MR restricted to females) and presence of affected females. The distinction between specific and nonspecific conditions should intuitively have a molecular correlate. Actually, one can speculate that MRXS genes code for proteins with a broad range of molecular targets (eg transcriptional regulators such as XNP/ATR-X or protein kinases such as RSK2), while most of 
Table 5 MRX cloned genes

\begin{tabular}{|c|c|c|c|c|c|}
\hline MIM No. & Name & Locus & Gene & Includes & Excludes \\
\hline *309548 & FRAXE & Xq28 & FMR2 & & \\
\hline *300104 & RABGDIA & $\mathrm{Xq} 28$ & GDI1 & MRX41 and 48 & MRX3, 25, 28 and 16 \\
\hline *300127 & Oligophrenin-1 & $\mathrm{Xq} 12$ & OPHN1 & MRX60 & MRX14 and 52 \\
\hline *300142 & p21 Act. Kinase 3 & $\mathrm{Xq} 22$ & PAK3 & MRX30 and 47 & \\
\hline *300206 & IL1 Rec acc. Protein & Xp22.1-p21.3 & IL1RAPL & MRX34 (deletion at DXS1218) & $M R \times 2,36,43,54$ \\
\hline *300096 & Tetraspanin & Xp11.4 & TM4SF2 & & MRX 15 and 55 \\
\hline *300267 & $\alpha \mathrm{PIX}$ & $\mathrm{Xq} 26$ & ARHGEF6 & MRX46 & \\
\hline
\end{tabular}

Table 6 XLMR genes: update 2000

\begin{tabular}{lccc}
\hline & Total & Mapped & Cloned \\
\hline Malformations syndromes & 79 & 34 & 7 \\
Neuromuscular disorders & 37 & 18 & 6 \\
Metabolic conditions & 12 & 2 & 10 \\
Dominant conditions & 8 & 4 & 3 \\
Total MRXS & 136 & 58 & 26 \\
MRX & 66 & 59 & 7 \\
Total entries & 202 & 117 & 33
\end{tabular}

the MRX genes now cloned seem to produce proteins with more limited and specific tasks ${ }^{10,11}$ (eg regulating the shuttling of synaptic vesicles or modulating the establishment of synaptic contacts between neurons). This hypothesis will need further experimental support, also to explain such discrepancies as observed for the RSK2 gene mutated in the Coffin-Lowry syndrome and in the nonspecific MRX19 family, $^{12}$ or for the MeCP2 gene responsible for the Rett syndrome but also mutated in a small MRX family. ${ }^{13}$

\section{Listing and maps}

In Tables 1-4, which list the specific conditions, the name, the OMIM number or reference and a brief description are provided for every entry, while the gene localisation and the name of the gene are obviously indicated only where available. Table 1 contains several additions of syndromes described in the last 2 years. The presence of a second Simpson-Golabi-Behmel locus in Xp22 should be noted, ${ }^{14}$ as it underlines the possibility of genetic heterogeneity of clinically similar/identical conditions. On the other hand, a clear example of clinical variability is represented by the ATR-X syndrome. Mutations in the XNP gene have now been found in at least four other conditions, namely JubergMarsidi (\#309590), Carpenter-Waziri, ${ }^{15}$ Holmes-Gang, ${ }^{16}$ and a family with spastic diplegia, microcephaly and short stature. ${ }^{17}$ An XNP mutation was also found in a family reported as Smith-Fineman-Myers, ${ }^{18}$ though a separate entry for this latter condition is still included in Table 1. In this case 'lumping' of clinically distinguishable conditions has been possible after the gene cloning and re-screening of patients belonging to families with either a resembling phenotype or linkage to the same chromosomal interval. Until mutational screening allows more lumping, we are convinced that the wisest approach is 'splitting', ie considering as different any similar but not quite identical conditions, until proven otherwise. Linkage exclusion is sometimes very useful for splitting two conditions segregating in two small families that will not reach the threshold of LOD score significance. In Table 2, another example of lumping is offered by the spectrum of L1CAM mutations listed under HSAS (\#307000), but the most extreme example of clinical variability is presently represented by the RSK2 mutations causing either the Coffin-Lowry syndrome or a nonspecific MRX. ${ }^{12}$ It is instructive to note that the Zollino syndrome of pachygyria and $\mathrm{MR},{ }^{19}$ which was present in the 1998 update, has been excluded from this update because it was found to be due to a cryptic subtelomeric translocation. Table 3 lists metabolic conditions whose genes have almost all been cloned, while Table 4 summarises the information on eight X-linked dominant disorders; genes for three of these were recently cloned. Only one of these conditions, EFMR ( $\left.{ }^{*} 300088\right)$, is not lethal in males: actually it affects exclusively females and it has been hypothesised that the responsible gene may have a homologue on the $\mathrm{Y}$ chromosome. A brief note should be made here to remember that a skewed X-inactivation is often observed in carrier females of these dominant mutations. One may hypothesise that cells which inactivate the normal allele die preferentially during embryogenesis or divide less than those with the normal allele on the active X chromosome. Sometimes skewage of X-inactivation is observed also in female carriers of conditions which are not lethal in males (such as ATR-X). However, in many cases there is random Xinactivation, probably because no selection occurs during early development, and female carriers may have different degrees of involvement depending on the fraction of mutant alleles on the active $\mathrm{X}$ chromosome. In heterozygous females two distinct cell populations will exist side by side, as nicely demonstrated, for instance, by the formation of a 'double cortex' in female carriers of the XLIS (\#300067) mutant gene (Table 2). For reasons of space Table 5 lists only the cloned MRX genes; the complete listing of MRX conditions with their localisation can be retrieved from the on-line XLMR database. Several of these genes encode proteins involved in the control of the cytoskeleton 


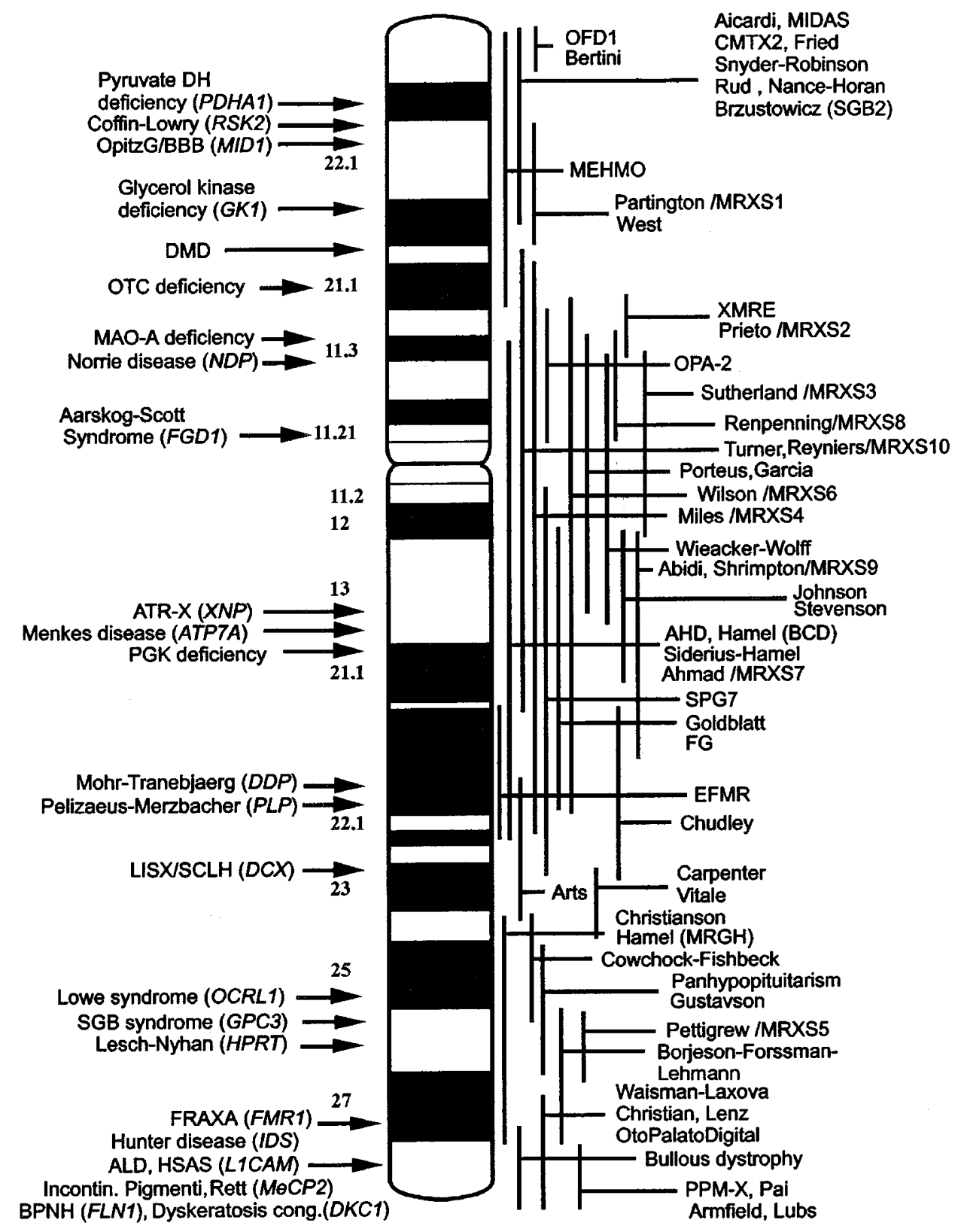

Figure 1 Ideogram of the X chromosome (G-banding) with the localisation of the 26 cloned (arrows) and 58 mapped (bars) MRXS genes.

and neurite outgrowth or in synaptic vesicle cycling, ${ }^{10}$ ie proteins that have a specific and limited task in the functioning of the central nervous system ${ }^{20}$ and will not disturb development nor impair cell viability. Table 6 has the total counts. A total of 202 conditions (136 MRXS and $66 \mathrm{MRX}$ ) have been included in this update (as of October 19, 2000). The genes of 117 of these (58 MRXS and 59 MRX) have been regionally mapped and 33 (26 MRXS and seven MRX) cloned. Figures 1 and 2 depict the cloned/mapped MRXS and MRX genes, respectively.

\section{The on-line XLMR database}

To integrate the published XLMR update we designed a simple on-line catalogue, the XLMR database, which is now available on the Internet at http://homepages.go.com/ $\sim \mathrm{xlmr} /$ home.htm. This is obviously no substitute for information derived from journals, books, expert systems and clinical experience, but it could become a useful tool if most of the fellow researchers will help to improve it and to keep it updated. Potentially, it offers a number of advantages over any published document: it can be updated as 


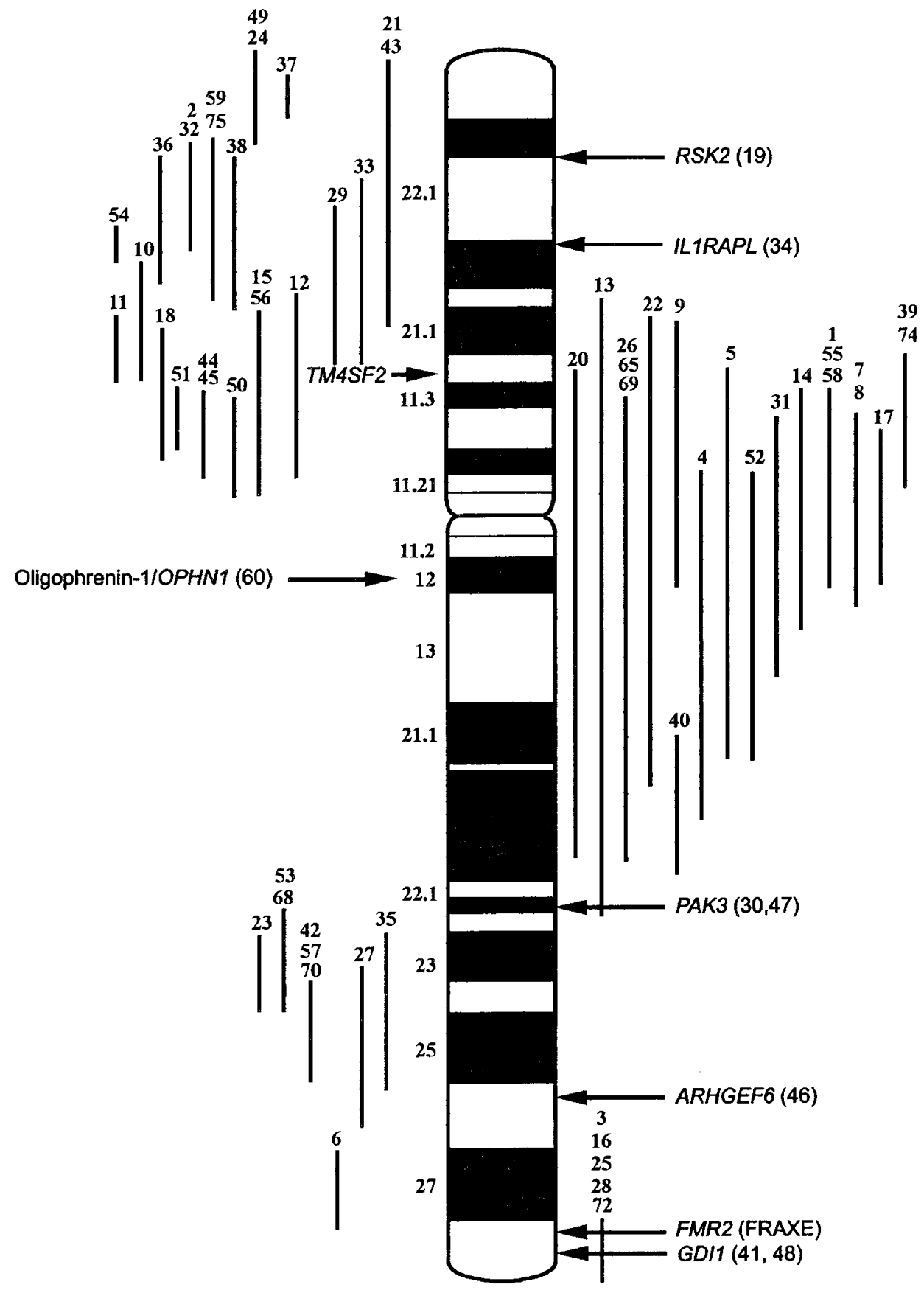

Figure 2 Ideogram of the $X$ chromosome (G-banding) with the localisation of the seven cloned MRX genes (arrows) and of the 59 mapped MRX families (bars). The extra cloned gene indicated is RSK2, which is also depicted in Figure 1 and most often mutated in the Coffin-Lowry syndrome (Table 1).

frequently as needed and there is much more space for additional information that may never be published. Presently, the on-line catalogue contains an expanded version of Tables 1-6 of this update (extra columns are available and the OMIM numbers and references are hyperlinked). A colour-coded version of Figures 1 and 2 is also available and we plan to hyperlink the conditions mentioned there with the corresponding Tables. An individual record for every condition would be highly desirable, possibly with more information on the cloned genes (with a link to Locuslink of NCBI, at least). Also, thanks to the space available, the complete linkage data might be attached and 
information on all tested loci (and not only recombinant ones) could be compared between overlapping conditions. Negative linkage data, which are not easily publishable but still very relevant and useful, may be stored. Eventually, images could be attached to the card describing each specific XLMR condition. Finally, a listing of available DNA from small families or individual cases with cytogenetic rearrangements in the various laboratories researching on XLMR may be envisaged, which would certainly boost the opportunity for collaboration. In brief, this informal Web site could become a 'meeting point' for the XLMR community.

\section{Future research}

Although the primary sequence of the human genome will soon be completed, the cloning era is far from being concluded and much 'sequence mining' and 'traditional' cloning remains to be done to account for the 202 XLMR conditions listed in this update. Many of these may eventually prove to be due to mutations in the same gene but the present number of 33 cloned XLMR genes definitely falls short of the actual amount. Unexpectedly, mutations in already cloned genes were not found to account for mental retardation in families mapping to the same narrow intervals where these genes are located. Therefore, new strategies will have to be designed to exploit even small families and individual patients for the identification of new XLMR genes. Some recent observations are encouraging. We now appreciate the value that even small families or individual patients with cytogenetic rearrangements can have in helping to pin down the remaining genes. For example, the MRX genes IL1RAPL and TM4SF2 were identified thanks to the observation of patients with a microdeletion and an X;autosome translocation, respectively, and confirmatory mutations were found in small families that could not reach a linkage significance. DNA chip technology will hopefully allow (re)screening of large numbers of patient DNAs for mutations in several candidate genes at the same time, as well as testing the expression of these genes in informative families. Finally, the next challenge awaiting us will be the unravelling of the structure and function of the proteins encoded by the XLMR genes. This will be a daunting task belonging to the new era of 'proteomics' but will surely lead us to a better understanding of the biological pathways required for the normal development of intelligence.

\section{Acknowledgements}

The authors are greatly indebted to the many colleagues and fellow scientists all over the world who have brought to our attention items to be included or excluded, additional references and other relevant information.

\section{References}

1 Chiurazzi P, Oostra BA: Genetics of mental retardation. Curr Opin Pediat 2000; 12: 529-535.

2 Lehrke R: Theory of X-linkage of major intellectual traits. Am J Ment Defic 1972; 76: 611-619.

3 Turner G, Turner B: X-linked mental retardation. J Med Genet 1974; 11: 109-113.

4 Neri G, Chiurazzi P: X-linked mental retardation. Adv Genet 1999; 41: 55 - 94 .

5 Herbst DS, Miller JR: Nonspecific X-linked mental retardation II: the frequency in British Columbia. Am J Med Genet 1980; 7: $461-469$.

6 Turner G, Webb T, Wake S, Robinson H: Prevalence of fragile X syndrome. Am J Med Genet 1996; 64: 196-197.

7 Neri G, Gurrieri F, Gal A, Lubs HA: XLMR genes: update 1990. Am J Med Genet 1991; 38: 186-189.

8 Lubs H, Chiurazzi P, Arena J, Schwartz C, Tranebjaerg L, Neri G: XLMR genes: update 1998. Am J Med Genet 1999; 83: $237-247$

9 Hamel B, Chiurazzi P, Lubs H: Syndromic XLMR genes (MRXS): update 2000. Am J Med Genet, 2000; 94: 361-366.

10 Chelly J: Breakthroughs in molecular and cellular mechanisms underlying X-linked mental retardation. Hum Mol Genet 1999; 8: $1833-1838$

11 Toniolo D, D'Adamo P: X-linked non-specific mental retardation. Curr Opin Genet Dev 2000; 10: 280-285.

12 Merienne K, Jacquot S, Pannetier S et al: A missense mutation in RPS6KA3 (RSK2) responsible for non-specific mental retardation. Nat Genet 1999; 22: 13-14.

13 Orrico A, Lam CW, Galli L et al. MeCP2 mutation in male patients with non-specific X-linked mental retardation. FEBS Lett 2000; 24106: $1-4$.

14 Brzustowicz LM, Farrell S, Khan MB, Weksberg R: Mapping of a new SGBS locus to chromosome Xp22 in a family with a severe form of Simpson-Golabi-Behmel syndrome. Am J Hum Genet 1999; 65: 779-783.

15 Abidi F, Schwartz CE, Carpenter NJ, Villard L, Fontes M, Curtis $\mathrm{M}$ : Carpenter-Waziri syndrome results from a mutation in XNP. Am J Med Genet 1999; 85: 249-251.

16 Schwartz C, Abidi A, Lubs H, Stevenson R: A mutation in $X N P$ results in the Holmes-Gang syndrome: further evidence that mutations in $X N P$ may account for a relatively large fraction of mental retardation in males. Eur J Hum Genet 1999; 7 (S1): 37.

17 Lossi AM, Millan JM, Villard L et al: Mutation of the XNP/ATR-X gene in a family with severe mental retardation, spastic paraplegia and skewed pattern of $\mathrm{X}$ inactivation: demonstration that the mutation is involved in the inactivation bias. Am J Hum Genet 1999; 65: $558-562$.

18 Villard L, Fontes M, Ades LC, Gecz J: Identification of a mutation in the XNP/ATR-X gene in a family reported as Smith-Fineman-Myers syndrome. Am J Med Genet 2000; 91: 83 85.

19 Zollino M, Mastroiacovo P, Zampino G, Mariotti P, Neri G: A new XLMR syndrome with characteristic face, hypogenitalism, congenital hypotonia and pachygyria. Am J Med Genet 1992; 43: $452-457$.

20 Antonarakis SE, Van Aelst L: Mind the GAP, Rho, Rab and GDI. Nat Genet 1998; 19: 106-108.

21 Siber M: X-linked recessive microencephaly, microphthalmia with corneal opacities, spastic quadriplegia, hypospadias and cryptorchidism. Clin Genet 1984; 26: $453-456$.

22 Abidi F, Hall BD, Cadle RG et al: X-linked mental retardation with variable stature, head circumference, and testicular volume linked to Xq12-q21. Am J Med Genet 1999; 85: 223-229.

23 Ahmad W, De Fusco M, ul Haque MF et al: Linkage mapping of a new syndromic form of X-linked mental retardation, MRXS7, associated with obesity. Eur J Hum Genet 1999; 7: 828-832. 
24 Aldred MA, Dry KL, Knight-Jones EB et al: Genetic analysis of a kindred with X-linked mental handicap and retinitis pigmentosa. Am J Hum Genet 1994; 55: 916 - 922.

25 Armfield K, Nelson R, Lubs HA et al: X-linked mental retardation syndrome with short stature, small hands and feet, seizures, cleft palate, and glaucoma is linked to Xq28. Am J Med Genet 1999; 85: 236-242.

26 Atkin JF, Flaitz K, Patil S, Smith W: A new X-linked mental retardation syndrome. Am J Med Genet 1985; 21: 697-705.

27 Baraitser M, Reardon W, Vijeratnam S: Nonspecific X-linked mental retardation with macrocephaly and obesity: a further family. Am J Med Genet 1995; 57: 380-384.

28 Carpenter NJ, Givens H, Randell L, Lutz R, Miles JH: Clinical characterization and gene mapping of a family with X-linked mental retardation, facial dysmorphism, congenital hip dislocation and skewed pattern of X-inactivation. Am J Hum Genet 2000; 67(Suppl.2): 315.

29 Chudley AE, Tackels DC, Lubs HA et al: X-linked mental retardation syndrome with seizures, hypogammaglobulinemia, and progressive gait disturbance is regionally mapped between xq21.33 and Xq23. Am J Med Genet 1999; 85: $255-262$.

30 Golabi M, Ito M, Hall BD: A new X-linked multiple congenital anomalies/mental retardation syndrome. Am J Med Genet 1984; 17: $367-374$.

31 Hall BD, Robl JM: New X-linked MR/MCA syndrome associated with cleft lip/palate, upslanted/short palpebral fissures, high nasal bridge, prominent nasal tip, inguinal hernia and minor digital defects. Am J Hum Genet 1999; 65: A151.

32 Hamel BC, Mariman EC, van Beersum SE, Schoonbrood-Lenssen $\mathrm{AM}$, Ropers $\mathrm{HH}$ : Mental retardation, congenital heart defect, cleft palate, short stature, and facial anomalies: a new X-linked multiple congenital anomalies/mental retardation syndrome: clinical description and molecular studies. Am J Med Genet 1994; 51: $591-597$

33 Hockey A: X-linked intellectual handicap and precocious puberty with obesity in carrier females. Am J Med Genet 1986; 23: $127-137$.

34 Homfray T, Holland T, Patton M: A new X-linked mental retardation syndrome. Clin Dysmorphol 1995; 4: 289-293.

35 Johnson JP, Nelson R, Schwartz CE: A family with mental retardation, variable macrocephaly and macro-orchidism, and linkage to Xq12-q21. J Med Genet 1998; 35: 1026-1030.

36 Kang WM, Huang CC, Lin SJ: X-linked recessive inheritance of dysgenesis of corpus callosum in a Chinese family. Am J Med Genet 1992; 44: 619-623.

37 Lubs H, Abidi F, Bier JA et al. XLMR syndrome characterized by multiple respiratory infections, hypertelorism, severe CNS deterioration and early death localizes to distal Xq28. Am J Med Genet 1999; 85: 243-248.

38 Steinmuller R, Steinberger D, Muller U: MEHMO (mental retardation, epileptic seizures, hypogonadism and -genitalism, microcephaly, obesity), a novel syndrome: assignment of disease locus to xp21.1-p22.13. Eur J Hum Genet 1998; 6: $201-206$.

39 Oosterwijk JC, Wischmeijer A, Losekoot M, Haraldson A, Theunissen G, van Gelderen I: A new X-linked mental retardation syndrome with distal limb defects, hearing impairment, verrucosis and immunodeficiency. Am J Hum Genet 1999; 65: A337.

40 Porteous MEM, Johnson H, Burn J et al: A new mental retardation syndrome mapping to the pericentrometric region of the X chromosome. Am J Hum Genet 1992; 51: A106.

41 Reish O, Gorlin RJ, Hordinsky M, Rest EB, Burke B, Berry SA: Brain anomalies, retardation of mentality and growth, ectodermal dysplasia, skeletal malformations, Hirschsprung disease, ear deformity and deafness, eye hypoplasia, cleft palate, cryptorchidism, and kidney dysplasia/hypoplasia (BRESEK/BRESHECK): new X-linked syndrome? Am J Med Genet 1997; 68: 386-390.
42 Seemanova E, Lesny I: X-linked microcephaly, microphthalmia, microcornea, congenital cataract, hypogenitalism, mental deficiency, growth retardation, spasticity: possible new syndrome. Am J Med Genet 1996; 66: 179-183.

43 Shashi V, Berry MN, Shoaf S, Sciote JJ, Goldstein D, Hart TC: A unique form of mental retardation with a distinctive phenotype maps to Xq26-q27. Am J Hum Genet 2000; 66: 469-479.

44 Shrimpton AE, Daly KM, Hoo JJ: Mapping of a gene (MRXS9) for $\mathrm{X}$-linked mental retardation, microcephaly, and variably short stature to Xq12-q21.31. Am J Med Genet 1999; 84: 293-299.

45 Siderius LE, Hamel BC, van Bokhoven $\mathrm{H}$ et al: X-linked mental retardation associated with cleft lip/palate maps to Xp11.3q21.3. Am J Med Genet 1999; 85: 216-220.

46 Brooks SS, Wisniewski K, Brown WT: New X-linked mental retardation (XLMR) syndrome with distinct facial appearance and growth retardation. Am J Med Genet 1994; 51: 586-590.

47 Stevenson RE, Hane B, Arena JF et al: Arch fingerprints, hypotonia, and areflexia associated with $\mathrm{X}$ linked mental retardation. J Med Genet 1997; 34: 465-469.

48 dos Santos RC, Barretto OC, Nonoyama K et al. X-linked syndrome: mental retardation, hip luxation, and G6PD variant. Am J Med Genet 1991; 39: 133-136.

49 Stoll C, Geraudel A, Chauvin A: New X-linked syndrome of mental retardation, short stature, and hypertelorism. Am J Med Genet 1991; 39: 474-478.

50 Tariverdian G, Froster-Iskenius U, Deuschl G, Wolff G: Mental retardation, acromegalic face, and megalotestes in two halfbrothers: a specific form of X-linked mental retardation without fra $(\mathrm{X})(\mathrm{q})$ ? Am J Med Genet 1991; 38: 208-211.

51 Turner G, Gedeon A, Mulley J: X-linked mental retardation with heterozygous expression and macrocephaly: pericentromeric gene localization. Am J Med Genet 1994; 51: 575-580.

52 Vasquez SB, Hurst DL, Sotos JF: X-linked hypogonadism, gynecomastia, mental retardation, short stature, and obesitya new syndrome. J Pediatr 1979; 94: 56-60.

53 Vitale E, Specchia C, Devoto M et al: A novel X-linked mental retardation syndrome with short stature maps to Xq24. Am J Hum Genet 2000; 67(Suppl.2): 332

54 Vles JS, Fryns JP, Folmer K et al: Corpus callosum agenesis, spastic quadriparesis and irregular lining of the lateral ventricles on CT-scan. A distinct X-linked mental retardation syndrome? Genet Couns 1990; 1: $97-102$.

55 Wittwer B, Kircheisen R, Leutelt J, Orth U, Gal A: New X-linked mental retardation syndrome with the gene mapped tentatively in Xp22.3. Am J Med Genet 1996; 64: 42-49.

56 Young ID, Hughes HE: Sex-linked mental retardation, short stature, obesity and hypogonadism: report of a family. J Ment Defic Res 1982; 26: $153-162$.

57 Arena JF, Schwartz C, Stevenson R et al. Spastic paraplegia with iron deposits in the basal ganglia: a new X-linked mental retardation syndrome. Am J Med Genet 1992; 43: 479-490.

58 Dobyns WB, Berry-Kravis E, Havernick NJ, Holden KR, Viskochil D: X-linked lissencephaly with absent corpus callosum and ambiguous genitalia. Am J Med Genet 1999; 86: 331-337.

59 des Portes V, Bachner L, Bruls T et al: X-linked neurodegenerative syndrome with congenital ataxia, late-onset progressive myoclonic encephalopathy and selective macular degeneration, linked to Xp22.33-pter. Am J Med Genet 1996; 64: 69-72.

60 Cabezas DA, Slaugh R, Abidi F et al: A new X linked mental retardation (XLMR) syndrome with short stature, small testes, muscle wasting, and tremor localises to Xq24-q25. J Med Genet 1997; 37: $663-668$.

61 Claes S, Devriendt K, Van Goethem G et al: Novel syndromic form of X-linked complicated spastic paraplegia. Am J Med Genet 94: $1-4$.

62 Strain L, Wright AF, Bonthron DT: Fried syndrome is a distinct X linked mental retardation syndrome mapping to Xp22. J Med Genet 1997; 34: $535-540$. 
63 Garcia CC, Buddles MRH, Seager M, Goodship JA: A family with $\mathrm{X}$-linked epilepsy mapping to Xp11-Xq13. Am J Hum Genet 1999; 65: A250.

64 Hamel BC, Wesseling P, Renier WO et al: A new X linked neurodegenerative syndrome with mental retardation, blindness, convulsions, spasticity, mild hypomyelination, and early death maps to the pericentromeric region. J Med Genet 1999; 36: $140-143$.

65 Steinmuller R, Lantigua-Cruz A, Garcia-Garcia R, Kostrzewa M, Steinberger D, Muller U: Evidence of a third locus in X-linked recessive spastic paraplegia. Hum Genet 1997; 100: 287-289.
66 Tranebjaerg L, Lou H, Andresen J: New X-linked syndrome with apraxia, ataxia, and mental deficiency: clinical, cytogenetic and neuropsychological studies in two Danish families. Am J Med Genet 1992; 43: 498-504.

67 Hedera P, Alvarado D, Beydoun A, Fink JK: Novel mental retardation-epilepsy syndrome linked to Xp21.1-p11.4. Am J Hum Genet 2000; 67(Suppl.2): 332. 